\title{
Aerial Census of Wild Horses in Western Utah
}

MILTON N. FREI, J. SCOTT PETERSON, AND J. RON HALL

\begin{abstract}
The accuracy of aerial censuses in estimating absolute density of wildlife populations varies widely. Aerial censusing of wild horses was done to compare the effects of experience and aircraft type. The difference between aircraft types was not found to be statistically significant, while observer experience was significant at the $5 \%$ level. The variability caused by these factors places considerable uncertainty on projections of rate of increase based upon a comparison of two or more aerial censuses.
\end{abstract}

Aerial survey is the only practical means of counting larger animals in wilderness terrain (Fuller 1950), but is, at best, a rough method of estimating the size of a population (Caughley 1974). The literature contains no information on aerially censusing wild horses, but there is a wealth of data concerning large mammals. The various factors which affect the accuracy of aerial counts include variables related to observer (experience, fatigue, individual variation), animal (density, color, size, diurnal behavior pattern), technique (transect width, speed, height), physiography (terrain, vegetation), weather (clouds, turbulence, snow cover, light conditions), and equipment (aircraft type, pilot). In an aerial census of moose in 1-square mile enclosures, LeResche and Rausch (1974) found that seasoned observers without recent counting experience are as inaccurate as unseasoned observers. The accuracy of aerial censuses in estimating absolute density of wildlife populations varies from 29 to $88 \%$ (Caughley 1977).

In recent years, aerial censusing of wild horse populations has. indicated that populations are experiencing phenomenal growth. Heady and Bartolome (1977) indicate an increase in numbers from 66 to 120 and 225 on the Three Fingers and from 94 to 113 and 150 on the Jackies Butte horse management areas in Oregon for the consecutive years of 1972, 1973 and 1974, respectively. The above authors state that "although inaccurate counting and addition of adults to the herds cannot be ruled out in either area, the major increase reflects natural reproduction. The data for Jackies Butte are believed accurate and they suggest a reproductive rate of $60 \%$ in 3 years or $20 \%$ per year.', Two other examples of published data on rate of increase include an increase of $28 \%, 29 \%$, and $18 \%$ for 1973, 1974, and 1975 respectively, in Idaho's Challis Planning Unit (U.S. Dep. Interior 1975) and 30\% and 22\% for 1974 and 1975, respectively, in California's Susanville District (U.S. Dep. Interior 1976).

Authors are range conservationist, Bureau of Land Management, Denver Federal Center Denver, Colorado 80225; range conservationist, Botany and Plant Pathology, Colorado State University, Fort Collins, Colorado 80523; and wild horse specialist Bureau of Land Management, Winnemucca, Nevada 89445

The authors would like to thank Dr. Frederick K. Martinson, who provided technical assistance in statistical analysis of the data.

Manuscript received January 16, 1978.
The aerial surveys in the Challis Planning Unit were made by fixed-wing aircraft in 1973-74 and by helicopter in 1975. The type of aircraft used in the Susanville District was not identified.

It is our contention that a large portion of the above increases can be attributed to the noncompensating errors naturally inherent in aerial surveys. The present study is not intended to give an absolute count of a population, since aerial surveys of large mammals consistently underestimate densities (Golley and Buechner 1968; Bergerud 1963; LeResch and Rausch 1974; Gilbert and Grieb 1957). The purpose was to evaluate differences in the results of wild horse aerial censusing with regard to (1) the experience of personnel and (2) the type of aircraft used, particularly as related to projections of wild horse population increase.

\section{Study Area}

The study area is situated on the Dugway Proving Grounds in westcentral Utah (Fig. 1). The specific study sites within this area were the Granite Mountain and a portion of the Cedar Mountains with elevations ranging from 1,342 to 2,140 meters. These two areas were selected because the wild horse populations were isolated duc to topography. The areas were geographically dissimilar, particularly in size and terrain. Granite Mountain occupies approximately $110 \mathrm{~km}^{2}$ and resembles a butte. The slopes are rocky and very steep, with most horse activity on the adjacent flats. The Cedar Mountains, in comparison, have relatively accessible slopes, with many canyons along the range. This site comprises approximately $330 \mathrm{~km}^{2}$ with horse activity observed throughout.

Vegetation on Granite Mountain consisted of plant species common to the northern desert shrub community. Big sagebrush (Artemisia tridentata), black sagebrush (Artemisia nova), shadscale (Atriplex confertifolia) and winterfat (Ceratoides lanata) were the common shrubs in the area. Grasses and forbs included wheatgrass (Agropyron spp.), galleta (Hilaria jamesii), cheatgrass (Bromus tectorum), scarlet globemallow (Sphaeralcea coccinia), and lupine (Lupinus spp.). Visibility of horses not limited due to the open terrain and lack of trees.

Cedar Mountain was dominated by a juniper woodland, which was interspersed with open sagebrush parks along the ridges and canyon bottoms. Open flats bordered both sides of the mountain and contained vegetation common to the northern desert shrub community. Trees and shrubs included utah juniper (Juniperus osteosperma), big sagebrush, rubber rabbitbrush (Chrysothamnus nauseosus), shadscale, and black sagebrush. Wheatgrass, cheatgrass, galleta, Indian ricegrass (Oryzopsis hymenoides), scarlet globemallow, bladderpod (Lesquerella spp.) and tansymustard (Descurainia spp.) were common grasses and forbs. Visibility of horses was limited due to density of vegetation and complexity of topography.

All flights over the study area were conducted during the period February 28 through March 7, 1977. The Cedar Mountains were covered with a light blanket of snow during all flights conducted with the Jet-Ranger helicopter. Patchy snow conditions were encountered during all other flights. Light conditions were excellent to good for 16 


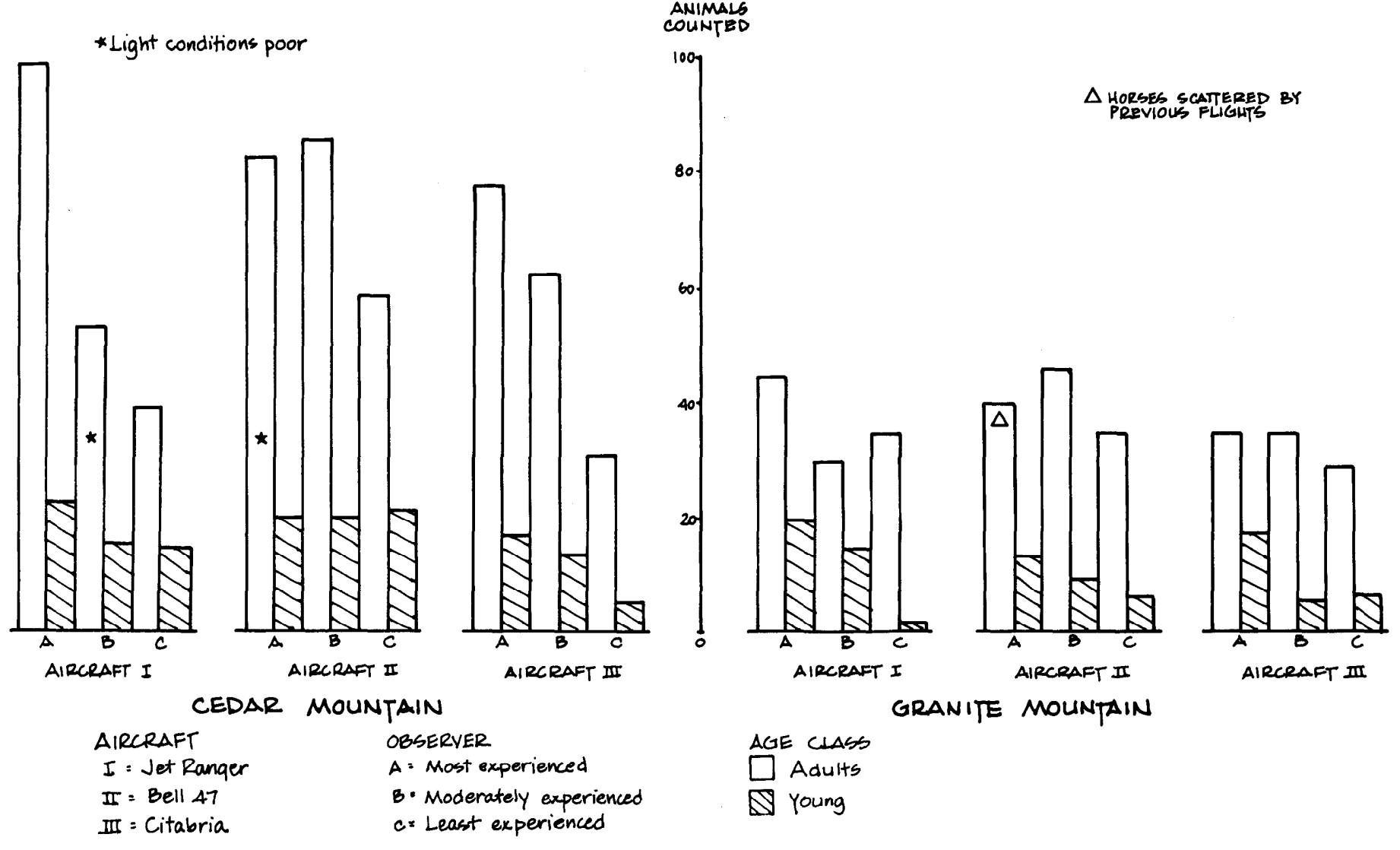

Fig. 3. Age class distribution of horse populations by experience of observer, aircraft type, and mountain range.

An analysis of variance was initially performed on the total animals derived from both mountains. The considered factors were (a) experience, (b) aircraft type, and (c) mountain. When analyzing the counts by analysis of variance, a lack of replication severely limited the degrees of freedom that could be used. Several sources of variation (aircraft, aircraft $\times$ experience, mountain $\times$ aircraft $\times$ experience) were pooled to produce an estimate of the error term. Visually (Figs. 2 and 3), the difference among factors looks significant, and statistically the comparison between mountains was significant at the $1 \%$ level, with experience being significant at the 5\% level. The large significance of the mountain factor and the lack of replications appeared to be masking the difference between aircraft. Because of this, and the larger population of Cedar Mountain, it was determined that statistical analysis be limited to the Cedar Mountain only.

An analysis of variance was next performed on the total animals counted on the Cedar Mountain. From these data, a comparison of computed versus table $F$ values (Table 1) demonstrated that the differences among aircraft were not significant at the $5 \%$ level while the differences among observer

Table 1. Analysis of variance for total wild horses counted on the Cedar Mountain.

\begin{tabular}{|c|c|c|c|c|c|c|}
\hline \multirow[t]{2}{*}{$\begin{array}{l}\text { Source of } \\
\text { variation }\end{array}$} & \multirow[t]{2}{*}{$\begin{array}{l}\text { Sum of } \\
\text { squares }\end{array}$} & \multirow[t]{2}{*}{$\begin{array}{l}\text { Degree of } \\
\text { freedom }\end{array}$} & \multirow[t]{2}{*}{$\begin{array}{c}\text { Mean } \\
\text { square }\end{array}$} & \multirow[t]{2}{*}{$\begin{array}{l}\text { Computed } \\
F \text { values }\end{array}$} & \multicolumn{2}{|c|}{$\begin{array}{c}\overline{\text { Table }} \\
F \text { values }\end{array}$} \\
\hline & & & & & 0.05 & 0.01 \\
\hline $\begin{array}{l}\text { Aircraft type } \\
\text { Observer }\end{array}$ & 522.9 & 2 & 261.4 & 2.15 & 6.94 & 18.00 \\
\hline experience & 2928.2 & 2 & 1464.1 & 12.04 & 6.94 & 18.00 \\
\hline Error & 486.4 & 4 & 121.6 & - & - & - \\
\hline Total & 3937.6 & 8 & - & - & - & - \\
\hline
\end{tabular}

experience were significant at the $5 \%$ level.

To obtain a pictorial representation of the differences among observer experience and aircraft type, an analysis of means following Ott (1975) was performed on the data. As shown in Figure 4 , the points representing the means of the counts obtained from each type of aircraft are contained within the .05 limits, thereby indicating their lack of significance at the $5 \%$ level. However, the spread of the means of the aircraft counts points towards a very positive difference between types of

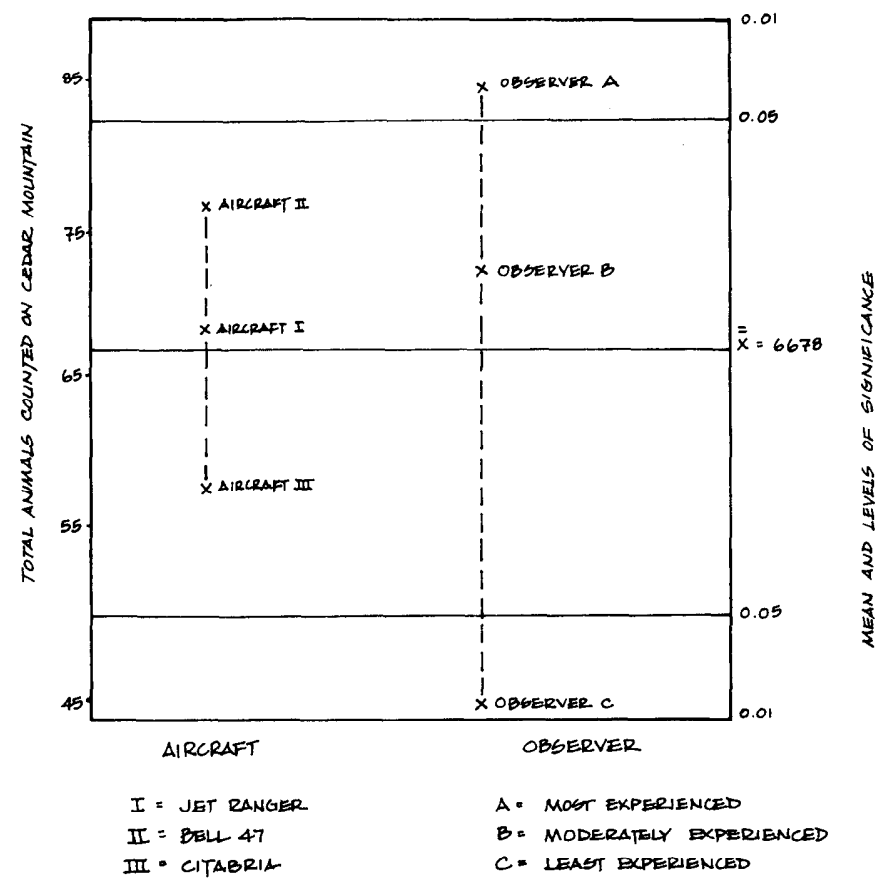

Fig. 4. Analysis of means. 
aircraft used. This can logically be attributed to the physical characteristics of each aircraft. Although not demonstrated statistically, it is felt that the analysis of means (Fig. 4) indicates the selection of aircraft will have a considerable affect on relative population counts.

The histograms (Figs. $2 \& 3$ ) illustrate the fact that the differences between experience were least when utilizing aircraft 2. This is thought to be a function of the slower speed and greater visibility of this aircraft. For these reasons the Bell 47 helicopter is considered to be the aircraft of choice, among those considered, in the aerial census of wild horses. Cost and horsepower limitations will be important considerations in selecting one of the types of aircraft.

\section{Conclusions}

Statistically, experience was the most significant factor analyzed in this study. The study illustrates that under similar conditions aerial counts on a wild horse population could increase significantly if successive counts are performed by more experienced personnel. To a degree this is an unavoidable variable, since experience will increase every time an aerial census is conducted. Therefore, the factor of experience alone could easily account for a significant portion of the large increases in numbers of wild horses that have been noted by aerial census. The results indicate that for the most accurate counts of relative wild horse numbers, only personnel with census experience should be used. Also, better counts will be obtained from those familiar with the area on the ground and from the air.
As a general conclusion, the authors believe the wide variability in animals counted, demonstrated by this study, places considerable uncertainty on rate of increase projections which are based upon a comparison of two or more aerial censuses. At best, aerial census will provide minimally acceptable estimates of wild horse population densities and broad overviews of population trend. Since population increase is a function of fecundity and survival, these factors should be important considerations in ratc of increase projections.

\section{Literature Cited}

Bergerud, A.T. 1963. Aerial winter census of caribou, J. Wildl. Manage. 27:438-449.

Caughley, G. 1974. Bias in aerial survey. J. Wildl. Manage. 38:921-933. Caughley, G. 1977. Analysis of Vertebrate Populations. John Wiley \& Sons, N.Y.

Fuller, W.A. 1950. Aerial census of bison in Wood Buffalo Park. J. Wildl. Manage. 14:445-451.

Gilbert, P.F., and J.R. Grieb. 1957. Comparison of air and ground deer counts in Colorado. J. Wildl. Manage. 21:33-37.

Golley, F.B., and H. Buechner. 1968. A practical guide to the study of the productivity of large herbivores. IBP Handbook No. 7 Blackwell Scientific Publications. Oxford and Edinburgh.

Heady, H.F., and J. Bartolome. 1977. The Vale rangeland rehabilitation program: The desert repaired in southeastern Oregon. U.S.D.A., PNWF\&RES, Forest Serv. Res. Bull. PNW-70.

LeResche, R.E., and R.A. Rausch. 1974. Accuracy and precision of aerial moose counting. J. Wildl. Manage. 38:175-182.

Ott, E.R. 1975. Process Quality Control. McGraw-Hill. N.Y.

U.S. Department of Interior. Draft Challis environmental impact statement. Bureau of Land Management.

U.S. Department of Interior. Susanville District wild horse and burro statistics. Bureau of Land Management (Unpublished).

\title{
Election Results
}

The 2,007 ballots cast in the 1978 election were counted on December 8 . Selected by the membership to serve the Society during the next 3 years were:

\author{
President Elect ..... Harold F. Heady \\ Directors ........ S. Clark Martin \\ Jack R. Miller
}

The new officers will be installed at the forthcoming Annual Meeting in Casper, at which time Daniel Merkel, the current president elect, will succeed to the presidency. Harold Heady will serve as president in 1980, and the two newly elected directors will serve for the 3-year term 1979-1981.

Retiring next month from the Board of Directors are Past President Thadis W. Box and Directors Edward A. McKinnon and Jeff Powell. The very significant service rendered to the Society by these men is greatly appreciated.

Dr. Harold F. Heady is at present assistant vice president for Agriculture and University Services and associate director of the Agricultural Experiment Station, University of California.

Dr. S. Clark Martin is principal range scientist with the Rocky Mountain Forest and Range Experiment Station, U.S. Forest Service, Tempe, Arizona. Jack R. Miller, is a range and wildlife specialist for the U.S. Forest Service, Missoula, Montana.

Members voted to amend Article 1, Section 6 of the Bylaws to read: Family (membership dues)-As shall be established from time to time by the Board of Directors.

Office staff at the SRM headquarters in Denver counted the ballots. Ballots and tally sheets are kept on file in the Society office for 1 year. 